\title{
KEBIJAKAN MUSEUM SONOBUDOYO YOGYAKARTA DALAM MENGATASI KLAIM KEPEMILIKAN WARISAN BUDAYA
}

\author{
Rendi Purnama ${ }^{1}$; Sri Rohyanti Zulaikha ${ }^{1}$ \\ ${ }^{1}$ Magister Ilmu Perpustakaan dan Informasi UIN Sunan Kalijaga Yogyakarta \\ Korespondensi: rendipurnama828@gmail.com
}

Diajukan: 02-10-2020; Direview: 22-10-2020; Direvisi: 15-12-2020; Diterima: 30-12-2020

\begin{abstract}
This study aims to explain the policies taken by the Sonobudoyo Yogyakarta Museum in overcoming crimes that may harm the Museum and the general public. This study uses a qualitative descriptive method through a case study approach that occurs at the Sonobudoyo Yogyakarta Museum. The result of this research is that the policy taken by the Sonobudoyo Museum is to no longer publish manuscript data or other manuscripts to minimize theft and ownership claims that occur. Manuscripts that are digitized are only published to people within the scope of the museum. So that there is no notification to the general public to avoid things that are not desirable. If you want to see manuscripts and ancient manuscripts, you can come directly to the Sonobudoyo Museum.
\end{abstract}

Keywords: Preservation, Manuscript, Sonobudoyo Museum, Digitalization

\begin{abstract}
ABSTRAK
Penelitian ini bertujuan untuk menjelaskan kebijakan yang diambil oleh Museum Sonobudoyo Yogyakarta dalam mengatasi kejahatan-kejahatan yang terjadi yang bisa merugikan pihak Museum dan masyarakat umum. Penelitian ini menggunakan metode deskriptif kualitatif yang melalui pendekatan studi kasus yang terjadi di Museum Sonobudoyo Yogyakarta. Hasil penilitian ini adalah Kebijakan yang diambil oleh Museum Sonobudoyo adalah dengan tidak lagi mempublikasikan data-data manuskrip ataupun naskah-naskah lain untuk meminimalisir pencurian dan klaim kepemilikan yang terjadi. Manuskrip yang didigitalisasi hanya dipublikasikan kepada orang-orang yang ada di ruang lingkup museum saja. Sehingga tidak ada pulikasi kepada masyarakat umum untuk menghindari hal-hal yang tidak diinginkan. Jika ingin melihat manuskrip dan naskah-naskah kuno bisa langsung datang ke Museum Sonobudoyo.
\end{abstract}

Kata Kunci: Preservasi, Manuskrip, Museum Sonobudoyo, Digitalisasi.

\section{PENDAHULUAN}

Daerah Istimewa Yogyakarta merupakan suatu daerah yang berada di Indonesia dan merupakan central dari pulau Jawa. Yogyakarta merupakan daerah dengan istimewa yang masih menganut sistem kerajaan dan masih sangat kuat dalam melestarikan dan mempertahankan budaya dan sumber-sumber sejarah yang ada (masih menjunjung tinggi kearifan lokal yang dimiliki). Oleh karena itu, Yogyakarta masih banyak menyimpan banyak naskah-naskah kuno yang berusia sangat tua sebagai bentuk sejarah-sejarah yang pernah dialami Yogyakara. Hingga saat ini naskah-naskah kuno yang ada masih dijaga dan dirawat dengan baik sehingga tidak menghilangkan esensi dari naskah tersebut. Tujuan perawat naskah tersebut adalah untuk menjaga nilai-nilai luhur yang berupa 
adat istiadat, budaya, dan serta sejarah yang ada. Hal ini seperti yang dilakukan di Museum Sonobudoyo Yogyakarta.

Museum banyak diartikan oleh banyak orang dengan tempat penyimpanan bendabenda kuno atau benda-benda sejarah saja. Pemikiran seperti ini tidaklah salah tetapi perlu penambahan diantaranya museum sebagai tempat penyimpanan data-data sejarah yang berupa naskah atau bentuk manuskrip yang tersimpan. Artinya barang-barang kuno yang memiliki nilai historis dan sejarah seperti artefak dan manuskrip. Di Yogyakarta Museum Sonobodyo masih sangat kuat dan menyimpan banyak barang-barang bersejarah seperti yang dijelaskan diatas. Museum Sonobudyo sebagai tempat untuk menyimpan bendabenda bersejarah awalnya dari Yayasan Java Institut yang berdiri tahun 1919 di Surakarta (Yanuarius: 2019, 12). Museum ini banyak menyimpan banyak manuskrip-manuskrip yang ada di Yogyakarta.

Koleksi manuskrip memiliki kandungan nilai sejarah dan informasi yang sangat penting bagi semua kalangan apalagi kalangan sejarawan yang banyak mencari data-data tentang sejarah sehingga manuskrip ini sangat penting bagi mereka. Karna nilai dan unsurnya sangat penting maka manuskrip harus dilestarikan dan dipertahankan eksistensinya. Salah satu sarana untuk melestarikan eksistensi dari manuskrip tersebut adalah dengan cara digitalisasi. Digitalisasi merupakan salinan yang dibuat dalam media lain atau sering disebut dengan alih media (Intan, 2019: 2). Namun pernyataan dari kepala Museum Sonobudoyo mengatakan upaya digitalisasi yang dilakukan Museum Sonobudoyo dimanfaatkan oleh oknum-oknum yang tidak bertanggung jawab untuk kepentingan pribadi dengan mencuri manuskrip yang sudah di digitalisasi sehingga permasalahan ini membuat pihak musem menutup diri untuk mempublish manuskrip- manuskrip yang ada di museum. Maraknya kejahatan dan pengakuan warisan budaya yang terjadi membuat Museum Sonobudoyo mengambil keputusan dan kebijakan untuk menyelamatkan warisan budaya yang saat ini di jaga dengan baik. Pencurian manuskrip merupakan hal yang tidak lazim karena manuskrip tersebut merupakan aset sejarah yang dimiliki suatu tempat. Jika pencurian manuskrip terjadi bisa berakibat fatal karena pencuri manuskrip tersebut bisa mengklaim kepemilikan dari mansukrip tersebut.

Berdasarkan uraian diatas peneliti tertarik untuk mengkaji startegi Museum Sonobudoyo dalam mengatasi klaim pemilikan warisan budaya dalam bentuk manuskrip. Tujuan penelitian ini adalah untuk mengetahui mengatasi klaim pemilikan warisan budaya dalam bentuk manuskrip.

\section{KAJIAN TEORI}

1. Kebijakan

Kebijakan dalam prespektif William N Dunn ialah kegiatan intelektual maupun praktis yang bertujuan untuk menciptakan, menilai secara kritis, serta menngkomunikasikan pengetahuan dalam proses kebijakan atau perumusan. Adapun tahap-tahap dalam mengambil kebijakan adalah: (Nugroho, 2009: 128).

a. Merumuskan masalah, merumuskan masalah bertujuan untuk problematika kongkrit yang terjadi sehingga bisa mendapatkan asumsi-asumsi yang bisa menjawab problematika yang terjadi sehingga bisa memetakan dan merancang sebuah kebijakan.

b. Permasalahan masa depan kebijakan, kebijakan yang diambil apabila dimasa yang akan datang terjadi permasalahan sehingga bisa menemukan alternatif dalam permasalahan-permasalahan yang akan muncul diwaktu yang akan datang. 
c. Rekomendasi kebijakan, rekomendasi ini merupakan bentuk saran yang akan diambil dalam merumuskan kebijakan.

d. Pemantauan hasil kebijakan, pemantauan ini berupa monitoring dari hasil kebijakan dengan memilah imapact maupun outputs dari kebijakan yang dibuat.

e. Evaluasi, merupakan penilaian atas kebijakan yang sudah terjadi sehingga menghasilkan kebijakan yang lebih baik dari sebelumnya.

2. Manuskrip sebagai warisan budaya

Manuskrip merupakan sumber primer yang outentik dalam kajian sejarah. Manuskrip bisa mengantarkan seseorang kepada masa lalu dengan peristiwaperistiwa yang terjadi. Manuskrip juga bisa menjadi jembatan dari masa lalu dan masa sekarang yang artinya bisa menjembatani kajian dan pengetahuan sehingga memberikan khazanah intelektual yang runtun dari masa lalu sampai berkembang ke masa sekarang bahkan bisa terus mengalami perkembangan serta mengetahui sejarah sosial di masa lalu dan kehidupan sosial di masa lalu (Oman, 2010: 3-4). Manuskrip bisa dijadikan data primer dalam ilmu sejarah karena terdapat informasi mengenai kehidupan sejarah yang terjadi di masa lalu sehingga menjadi tolak ukur masayarakat untuk berprilaku dan bertingkah laku di masa sekarang dan yang akan datang. Suatu dokumen ataupun arsip bisa dikatakan manuskrip apabila sudah berusia limapuluh tahun ke atas (Suradi, 1992:1).

Manuskrip bisa diartikan sebagai tulisan tangan yang di dalamnya terdapat berbagai gagasan dan pemikiran tentang hasil budaya yang terdapat di masa lalu yang mengandung nilai-nilai historis (Pudjiastuti, 2006: 9). Sesuatu tulisan ataupun dokumen yang bisa dikatakan sebagai manuskrip adalah tulisan ataupun dokumen yang sudah berusia lima puluh tahun ke atas yang memiliki nilai dan gagasan yang ada ataupun memiliki nilai historis. Manuskrip dalam prespektif ilmu arsip adalah dokumen yang menggunakan media kertas yang ditulis dengan tulisan tangan maupun mesin cetak yang berupa mesin tik di masa lalu seperti buku, surat, catatan, silsilah keturunan, dan lain sebagainya yang berupa naskah. Adapun menurut Mazyah (2005: 13) informasi yang terdapat di dalam manuskrip tidak diterbitkan dan menggunakan media kertas. Pada prinsipnya manuskrip adalah data yang sangat diperlukan oleh para sajarawan untuk mengungkap fakta sejarah serta mengetahui kebudayaan-kebudayaan yang ada.

Manuskrip pada esensinya banyak merekam informasi serta pengetahuan masayarakat di masa lalu sehingga bisa melihat warisan budaya yang ada pada masa lalu. Warisan ini bermacam-macam dan dimiliki oleh seluruh dunia yang ditulis dengan berbagai macam aksara seperti aksara jawa, aksara arab melayu, dan lain sebagainya (Widiesha, 2013: 1). Manuskrip dengan berbagai macam manfaat dan kepentingan didalamnya maka perlu seharusnya manuskrip ini dilestarikan sehingga eksistensinya tetap terjaga. Manuskrip ini memiliki berbagai informasi tentang segi-segi dan kondisi sosial masyarakat masa lalu (budaya yang ada di masa lalu).

Adat istiadat, nilai dan norma yang terdapat di masyarakat, perilaku, sistem hukum di masa lalu, dan aturan-aturan khusus yang mengikat di masa lalu merupakan nilai budaya yang terkandung didalam manuskrip. Adapun manuskrip yang berada di Museum Sonobudoyo Yogyakarta selain fungsinya menjadi 
benda warisan budaya di Yogyakarta juga berperan dalam proses eksistensi budaya di Yogyakarta. Manuskrip yang terdapat di Museum Sonobudoyo Yogyakata berjumlah 1350 yang terdiri dari manuskrip yang berasala dari daun lontar dengan jumlah 300 manuskrip. Jenis manuskrip yang ada di Museum Sonobudoyo ini berisi tentang manuskrip yang berupa sejarah, agama Islam, Bahasa, Primbon dan Pawukon, Surat keputusan, Hukum dan Peraturan, Silsilah, Wayang, Sastra Wayang, Sastra, Piwulang dan Suluk, Adat Istiadat, dan lain sebagainya (Fiqrie, 2019: 2). Manuskrip ini sangat penting bagi eksistensi kebudayaan sehingga sangat penting dipertahankan dan dijaga. Adapun cara dalam menjaga nilai-nilai manuskrip ini adalah dengan mengadakan kegiatan preservasi.

3. Preservasi

Preservasi menurut Lasa HS (2009: 287) merupakan unsur pengelolaan, penyimpanan, alat-alat bantu, ketenagakerjaan, ataupun metode yang dapat digunakan untuk melestarikan bahan pustaka, dokumentasi, arsip, ataupun informasi yang dikandungnya. Sedangkan Amjad (2014: 110-111) berpendapat tentang presevasi yaitu kegiatan perawatan jangka panjang yang terfokus kepada koleksi perpustakaan yang dilakukan dengan cara perawatan, pencegahan, serta perbaikan dan pemulihan pengobatan. Pada prinsipnya preserpasi merupakan kegiatan yang dilakukan untuk mempertahankan dan memperpanjang usia dari suatu dokumen atau arsip agar tetatap selalu eksis. Kegiatan preservasi meliputi perawatan dan pemeliharaan arsip yang bertujuan untuk mempertahankan dan meminimalisir kemungkinan hilangnya sumber ataupun nilai informasi yang ada di dalam arsip. Maka dari itu untuk menghindari kerusakan perlu adanya perawatan yang membuat nyaman arsip tersebut dengan memperhatikan suhu, tempat (agar terhindar dari debu), dan melakukan penyimpanan yang aman sehingga kecil kemungkinan arsip tersebut mengalami kerusakan. Inti dari perservasi adalah penjagaan dan pemeliharaan aset seperti manuskrip dan dokumen-dokumen lainnya agar terhindar dari kerusakan.

Penjagaan nilai-nilai informasi yang terkandung di dalam manuskrip dan mempertahankan bentuk fisik dari manuskrip merupakan suatu yang sangat penting untuk dipikirkan agar manuskrip tetap utuh dan terjaga. Untuk penjagaan manuskrip tersebut dapat digunakan dengan penanganan yang bersifat tradisional mapun yang modern. Penganan ini memiliki plus dan minus (kelebihan dan kekurangannya) masing-masing. Saat ini manusia dihadapkan dengan perkembangan zaman yang sangat pesat dan di hadpkan dengan era modernitas yang begitu kuat dan tinggi, dimana ilmu pengetahuan dan teknologi sedang berkembang begitu cepat. Perkembangan ilmu pengetahuan dan teknologi tersebut memberikan dampak yang begitu baik bagi keselamatan dan pelestarian manuskrip yang ada. Di era modern ini dengan kecanggihan teknologi, mempertahankan eksistensi manuskrip bisa menggunakan upaya digitalisasi (alih media digital) sehingga nilai dan informasi yang ada pada manuskrip bisa terjaga dan tetap bertahan sampai kapanpun.

Lee (2001: 29) mengemukakan digitalisasi adalah proses konversi dari media analog ke digital. Berangkat dari definisi yang dikemukan oleh Lee tersebut digitalisasi dapat diartikan menyalin nasakah atau manuskrip yang ada dengan mengalihkannya ke media lain atau ke dalam media digital. Seperti yang 
dikemukakan diatas tujuan digitalisasi adalah untuk mempertahankan nilai-nilai yang terkandung di dalam manuskrip yaitu informasi, selain itu digitalisasi juga merupakan bentuk dari penjagaan dan pelestarian bentuk fisik dari manuskrip tersebut sehingga manuskrip tersebut bisa dinikmati sampai kapanpun dan bisa bertahan lama (berumur panjang). Aktivitas digitalisasi ini memberikan dampak positif bagi lembaga-lembaga yang bergelut di dalamnya seperti perpustakaan, lembaga kerasipan, maupun museum. Dampak positif yang diberikan menurut Atmoko (2015: 1) adalah:

a. Melindungi dan mewakili sumber aslinya.

b. Lebih mudah dalam pengelolaan dan cepat dalam proses temu kembali informasi

c. Lebih mudah dalam penyimpanan dan hemat sehingga tidak memerlukan ruangan yang besar.

d. Lebih interaktif atau konten multimedia.

e. Lebih mudah dalam penyebaran informasi (disseminasi informasi)

f. Lebih mudah dalam pengadaan dan back up data.

Digitalisasi merupakan cara untuk mengatasi ancaman kerusak yang saat ini terjadi, kerusakan ini bisa dilakukan oleh individu-individu yang tidak bertanggung jawab dengan melakukan tindakan vandalisme, selain itu kerusakan juga bisa terjadi dengan adanya bencana alam dan hama binatang seperti rayap dan ancamanancaman lain yang bisa merusak keadaan fisik dari manuskrip tersebut. Tindakan untuk melakukan digitalisasi dirasa sangat penting dilakukan sehingga manuskrip maupun naskah tetap bisa terjaga dengan baik dan tetap lestari.

\section{METODE PENELITIAN}

Penelitian ini merupakan penelitian dengan menggunakan metode deskriptif kualitatif yang melalui pendekatan studi kasus. Teknik pengumpula data yang digunakan dalam penelitian ini adalah melalui wawancara. Wawancara merupakan pengumpulan data dengan cara tanya jawab dengan informasi penilitian yaitu kepala Museum Sonobodudoyo dan pengelola manuskrip Museum Sonobudoyo.

\section{HASIL DAN PEMBAHASAN}

1. Preservasi Manuskrip di Museum Sonobudoyo Yogyakarta

Preservasi manuskrip merupakan segala aktivitas yang dilakukan untuk memperpanjang umur dari suatu manuskrip yang termasuk di dalamnya adalah aktivitas perawatan dan pemeliharaan manuskrip sehingga manuskrip tersebut bisa bertahan sehingga bisa dimanfaatkan informasinya untuk khalayak ramai sehinggabisa menarik informasi di dalam manuskrip yang pernah ditulis. Kegiatan preservasi ini sering dan rutin dilakukan di Museum Sonobudoyo dalam rangka mempertahankan nilai budaya baik manuskrip yang sudah berumur sangat tua sampai manuskrip yang baru (tidak terlampau tua). Preservasi memiliki peran yang sangat penting dalam aspek pelindungan dan penyelamatan koleksi dari berbagai macam ancaman kerusakan, apalagi dalam konteks manuskrip yang sangat rawan terhadap berbagai macam kerusakan karena terbuat dari kertas yang memiliki tekstur yang tipis dan kertas yang berumur cukup tua membuat manuskrip rawan terhadap kerusakan.

Museum Sonobudoyo memahami preservasi ini merupakan bentuk kegiatan yang meliputi tentang perawatan, pembersihan benda museum yang sudah rapuh seperti manuskrip yang harus ditangani dengan khusus dan benar-benar 
dijaga dengan baik seheingga selalu terpelihara dan tetap relevan. Museum Sonobudoyo selalu melakukan preservasi manuskrip dengan rutin. Tujuannya adalah untuk mempertahankan dan memperhatikan manuskrip agar tidak rusak, selain itu tujuan lainnya adalah untuk melihat bentuk fisik dari manuskrip tersebut kuat atau tidak sehingga bisa dilakukan antisipasi dan penangan yang akan dicanangkan ketika ada manuskrip yang mangalami kerusakan (Fiqrie, 2019: 7).

2. Tahapan Preservasi Manuskrip di Museum Sonobudoyo Yogyakarta

Tahap yang paling dasar untuk melakukan preservasi adalah dengan mencari penyebab dari kerusakan sehingga bisa menghindari kerusakannya dengan melakukan suatu tindakan. Tindakan yang diambil untuk mencegah kerusakan dari fisik manuskrip ataupun naskah bisa dilakukan dengan memasukkannya ke dalam kotak kaca. Tujuan dari memasukkannya ke dalam kaca adalah untuk membuat suhu yang lebih baik bagi manuskrip atau naskah di dalam kotak kaca tersebut. Apabila kegiatan ini masih ada potensi kerusakan seperti masih adanya telur serangga atau yang lainnya maka langkah selanjutnya yang diambil adalah dengan mengadakan kegiatan freezing.

Tahap freezing ini manuskripmanuskrip dibungkus dengan pelastik untuk menjaga atau melindungi naskah dari bunga es yang muncul disaat kegiatan freezing, naskah akan dikeluarkan dengan alat vacum sealer agar tidak terjadi proses kondensasi ketika freezing. Kemudian setelah freezing naskah akan dibersihkan dengan menggunakan kuas. Apabila dari kegiatan-kegitan yang dilakukan masih didapati kerusakan-kerusakn yang terjadi pada fisik naskah maka maka proses selanjutnya adalah dengan melakukan kegiatan restorasi. Salah satu cara preservasi di Museum Sonobudoyo Yogyakarta untuk mempertahankan manuskrip agar selalu eksis dan bisa digunakan oleh masyarakat banyak sampai kapanpun adalah dengan menggunakan cara digitalisasi.

Manuskrip pada prinsipnya memiliki nilai yang sangat penting dan merupakan arsip statis yang kaya akan informasiinformasi sejarah dan kebudyaan yang terjadi di masa lalu, yang terpenting manuskrip tersebut merupakan pusat rekaman dan jejak masa lalu yang berisikan peristiwa-peristiwa yang dilestarikan untuk memberikan informasi dan edukasi kepada generasi-generasi berikutnya. Kebijakan untuk mendigitalisasi manuskrip merupakan suatu hal yang sangat penting mengingat begitu besarnya nilai historis yang terdapat pada manuskrip sehingga keberadaan dan nilai informasi yang terkandung tetap bertahan.

3. Proses Pelestarian dan Penyelamatan Informsi pada Manuskrip di Museum Sonobudoyo Yogyakarta

Digitalisasi merupakan cara untuk mengatasi ancaman kerusak yang saat ini terjadi, kerusakan ini bisa dilakukan oleh individu-individu yang tidak bertanggung jawab dengan melakukan tindakan vandalisme, selain itu kerusakan juga bisa terjadi dengan adanya bencana alam dan hama binatang seperti rayap dan ancamanancaman lain yang bisa merusak keadaan fisik dari manuskrip tersebut. Digitalisasi pada prinsipnya dilakukan karna melihat kondisi fisik manuskrip yang tua sehingga memungkinkan terjadi kerusakan dan bisa berpotensi untuk menghilangkan informasi yang terkandung di dalamnya, sehingga digitalisasi dirasi bisa memberikan eksistensi dari manuskrip tersebut. Alasan ini merupakan salah satu faktor yang menyebabkan didigitalisasinya manuskrip 
di Museum Sonobudoyo, alasan yang mengatakan bahwa kondisi fisik manuskrip yang semakin hari semakin tua dan mulai mengalami kerapuhan sehingga perlu adanya penanganan dengan cepat dalam mempertahakan manuskrip tersebut.

Proses digitalisasi pada manuskrip bertujuan untuk melestarikan fisik manuskrip, mempertahankan informasi pada manuskrip, dan mempermudah dalam proses pengaksesan pada generasi berikutnya. Manfaat dari digitalisasi yang dilakukan tidak hanya menguntungkan pihak museum saja tetapi yang lebih esensinya adalah bermanfaat untuk para pengunjung dan peniliti yang ingin mengetahui isi dari manuskrip tersebut. Intan Prastiani (2019: 6) mengatakan ada 4 manfaat dari digitalisasi, yaitu:

a. Mempermudah layanan akses yang diberikan kepada para pengunjung dan peneliti.

b. Mempertahakan fisik dan nilai informasi pada manuskrip.

c. Mempermudah dalam membaca naskah karena bisa diakses.

Efisiensi (lebih praktis, cepat dan ekonomis.Proses digitalisasi manuskrip bisa dilakukan dengan alat scanner, kegiatan ini bisa dilakukan oleh staf yang profesional dan berkompeten di dalam bidang alih media. Tahapan digitalisasi manuskrip bisa dilakukan dengan langkahlangkah seperti seleksi naskah (manuskrip), setelah proses penyeleksian maka dilakukan proses pengambilan gambar ataupun scan, kemudian setelah proses pengambilan foto atau scaning maka akan dilakukan proses editing yang meliputi cropping (pemotongan) untuk memratakan naskah selain cropping proses lain yang dilakukan adalah proses contrass (pencahayaan) agar naskah tersebut lebih cerah dan mudah untuk dibaca, setelah editing maka akan dilakukan penggabungan naskah tersebut dengan menggunakan corel draw pada microsoft, setelah file dirasa sudah rapi maka file tersebut disimpan.

4. Kebijakan yang diambil Museum Sonobudoyo Yogyakarta dalam Mencegah Kasus Pencurian Manuskrip

Seperti yang diketahu manuskrip yang terdapat di Museum Sonobudoyo Yogyakata berjumlah 1350 yang terdiri dari manuskrip yang berasala dari daun lontar dengan jumlah 300 manuskrip. Jumlah yang banyak ini harus di jaga dengan baik dan benar dan harus didigitalisasi agar tetap brtahan. Digitalisasi yang dirasa untuk mempermudah pengaksesan bagi para pengunjung dan peneliti tidak selamanya berdampak baik bagi Museum Sonobudoyo sehingga banyak pihak yang merugikan Museum Sonobudoyo dengan mencuri data-data manuskrip yang didigitalisasi dan di publikasi. Banyak oknum-oknum yang tidak bertanggung jawab yang mencuri manuskrip tersebut dan mengklaim bahwa manuskrip tersebut adalah miliki mereka dan berpotensi menjual manuskrip yang sudah didigitalisasi ke pihak yang membutuhkan naskah-naskah kuno. Manuskrip merupakan warisan budaya yang tertera banyak informasi didalamnya sehingga membuat banyak pihak yang menginginkan manuskrip tersebut menjadi kepunyaan mereka. Pencurian data manuskrip yang dipublikasi oleh Museum Sonobudoyo pada beberapa waktu yang lalu banyak di klaim sebagai kepunyaan orang lain ujar kepala kasi yang menjaga manuskrip. Kejahatan inilah yang membuat Museum Sonobudoyo tidak lagi mempublikasi manuskrip-manuskrip yang sudah didigitalisasi.

Maraknya kejahatan dan pengakuan warisan budaya yang terjadi membuat Museum Sonobudoyo mengambil 
keputusan dan kebijakan untuk menyelamatkan warisan budaya yang saat ini di jaga dengan baik. Kebijakan yang diambil oleh Museum Sonobudoyo adalah dengan tidak lagi mempublikasikan datadata manuskrip ataupun naskah-naskah lain untuk meminimalisir pencurian dan klaim kepemilikan yang terjadi. Manuskrip yang didigitalisasi hanya dipublikasikan kepada orang-orang yang ada di ruang lingkup museum saja. Sehingga tidak ada pulikasi kepada masyarakat umum untuk menghindari hal-hal yang tidak diinginkan. Jika ada penilitian yang membutuhkan informasi baik yang bersangkutan dengan budaya maupun informasi yang terdapat pada manuskrip maka pencarian informasi tersebut langsung ke pihak Museum Sonobudoyo. Selain itu jika ingin melihat manuskrip dan naskah-naskah kuno bisa langsung datang ke Museum Sonobudoyo. Hal lain yang juga dilakukan oleh pihak Museum Sonobudoyo adalah dengan melakukan sistem keamanan ruang penyimpanan manuskrip seperti penngaturan akses dan melakukan pengaturan ruang simpan.

Kebijakan ini merupakan cara agar manuskrip-manuskrip tidak dicuri dan tidak diakui kepemilikannya. Sehingga situs warisan budaya yang ada tetap utuh dan mempertahankan eksistensi dari manuskrip tersebut. Apabila manuskrip tersebut dicuri dan diklaim kepemilikannya sangat merugikan museum Sonobudoyo Yogyakarta. Maka dengan kebijkan inilah eksistensi dari kebudayaan dan nilai-nilai informasi bisa terjaga dengan untuh dan tetap menjadi milik Museum Sonobudoyo pada umumnya dan milik masayarakat Yogyakarta pada khusunya.

\section{KESIMPULAN}

Manuskrip merupakan situs warisan budaya yang didalamnya terdapat banyak nilai informasi dan nilai historis yang terkandung. Manuskrip pada prinsipnya adalah suatu benda yang terbuat dari kertas dan ditulis diatas kertas dan memiliki usia yang sangat panjang dan renta terhadap kerusakan. Kerusakan manuskrip tersebut bisa disebabkan oleh beberapa faktor yaitu vandalisme pengunjung, hama yang disebabkan oleh rayap dan serangga, bencana alam dan lain sebagainya.

Karena renta terhadap kerusakan maka perlu adanya preservasi untuk membuat ketahanan dan memperpanjang usia dari manuskrip tersebut sehingga nilai-nilai informasi yang terkandung bisa selalu bertahan dan tetap eksis untuk generasi berikutnya. Salah satu preservasi yang dilakukan oleh Museum Sonobudoyo Yogyakarta dalam mempertahankan manuskrip adalah dengan mendigitalisasi manuskrip dan naskahnaskah kuno. Sayangnya pendigitalisasi yang dilakukan banyak disalah gunakan oleh oknum-oknum yang tidak bertanggung jawab sehingga banyak manuskrip yang dicuri dan diklaim kepemilikannya. Adanya pencurian ini membuat Museum Sonobudoyo mengambil kebijakan untuk tidak mempublikasi manuskripmanuskrip dan hanya dipublikasikan kepada kerabat-kerabat museum saja. Sehingga meminimalisir kejahatan-kejahatan yang terjadi. 


\section{DAFTAR PUSTAKA}

Ali, Amjad. Glossary of Library and Information Sciebce. New Delhi: Ess Publications. 2004.

Agusti, Fiqrie Restia. Wasito, Joko. "Preservasi Manuskrip di UPT Museum Sonobudoyo Sebagai Usaha Menjaga Eksistensi Budaya di Yogyakarta”. 2019.

Atmoko, Pitoyo Widhi. Digitalisasi dan Alih Media. Disampaikan di Acara Forum Komunikasi Pengelola Perpustakaan di Lingkungan Badan Diklat ESDM. Lihat $\quad$ https://lib.ub.ac.id/home/ image//2015/08/Digitalisasi.pdf. Diakses pada tanggal 8 Maret 2020.

Faturhman, Oman. Dkk. Filologi dan Islam Indonesia. Jakarta: Bandung Litbang. 2010 .

HS, Lasa. Kamus Kepustakawanan Indonesia. Yogyakarta: Pustaka Book Publisher.

HP, Suradi. Babad Nitik. Jakarta: Departemen Pendidikan dan Kebudayaan. 1992.

Mazyah, Siti. Dkk. Metode Preservasi dan Konservasi Arsip. Semarang: UNDIP. 2005.

Prastiani, Intan. Subekti, Slamet, "Digitalisasi Manuskrip Sebagai Upaya Pelestarian dan Penyelamatan Informasi (Studi Kasus Pada Museum Padya Pustaka Surakarta)". 2019.
Pudjiastuti, Titik. Naskah dan Studi Naskah: sebuah antologi Seri Kajian Filologi. Bogor: Akademia. 2006.

Putra, Yanuarius Vandana. "Pemanfaatan Museum Sonobudoyo Sebagai Sumber Belajar dan Destinasi Wisata di Yogyakarta”. Skripsi. Yogyakarta: Universitas Sanata Dharma. 2019.

Riant, Nugroho. Public Policy, Jakarta: PT Elex media komputindo kelompok Gramedia. 2009.

Widiesha, Gio David. "Pribadi Rasa Pangrasa Sorangan”. Skripsi. Bandung: Universitas Pendidikan Indonesia. 